\title{
48 \\ PERAN PENDAMPING BAGI ORANG DENGAN HIV/AIDS (ODHA)
}

\author{
Oleh \\ Darastri Latifah, Moch. Zainuddin, \& Nandang Mulyana
}

E-mail:

(darastrilatifah@gmail.com; moch.zainuddin57@gmail.com; mulyananandang@gmail.com)

\begin{abstract}
ABSTRAK
ODHA merupakan singkatan dari Orang Dengan HIV/AIDS. Apabila seseorang telah dinyatakan mengidap HIV/AIDS maka bukan hanya fisik yang menurun, namun juga psikis dan sosialnya turut terpengaruh. Hal ini dikarenakan ODHA akan dipandang negatif sehingga dijauhi atau dikucilkan oleh lingkungan sekitarnya bahkan keluarganya. Seringkali dukungan dari lingkungan sekitar dan keluarga tidak didapatkan oleh ODHA. Oleh karena itu, peran pendamping bagi ODHA menjadi sangat strategis dalam upaya mengembalikan keadaan dan kondisi ODHA menjadi lebih baik dari sebelumnya. Mengacu pada Parson, terdapat beberapa peran yang dapat dilakukan pekerja sosial dalam melakukan pendampingan terhadap ODHA. Pertama sebagai fasilitator, pendamping berperan memfasilitasi ODHA agar mampu menangani tekanan psikis dan sosial yang dialami. Kedua sebagai broker, pendamping berperan menghubungkan kebutuhan ODHA dengan sumber-sumber yang ada disekitarnya. Ketiga sebagai mediator, pendamping berperan sebagai penengah bagi ODHA dengan sistem lingkungan yang menghambatnya. Keempat sebagai pembela, pendamping berperan dalam membela hak ODHA dalam memenuhi kebutuhannya. Dan kelima sebagai pelindung, pendamping berperan melindungi ODHA dari situasi yang rentan dan tidak menguntungkan bagi ODHA.

Kata Kunci: pendamping, peran, ODHA, HIV/AIDS
\end{abstract}

\section{PENDAHULUAN}

ODHA merupakan sebutan bagi orang telah terinfeksi HIV/AIDS. HIV adalah singkatan dari Human Immunodeficiency Virus yang dapat menyebabkan AIDS dengan cara menyerang sel darah putih sehingga dapat merusak sistem kekebalan tubuh manusia yang pada akhirnya tidak dapat bertahan dari gangguan penyakit walaupun yang sangat ringan sekalipun. Sel darah putih sangat diperlukan untuk sistem kekebalan tubuh. Tanpa kekebalan tubuh maka ketika diserang penyakit tubuh kita tidak memiliki pelindung. Dampaknya adalah orang tersebut dapat meninggal dunia hanya terkena pilek biasa.

AIDS adalah singkatan dari Acquired Immune Deficiency Syndrome yang merupakan efek dari perkembangbiakan virus HIV dalam tubuh makhluk hidup. Virus HIV membutuhkan waktu untuk menyebabkan AIDS yang mematikan dan sangat berbahaya. Untuk menjadi AIDS dibutuhkan waktu yang lama, yaitu beberapa tahun untuk dapat menjadi AIDS yang mematikan. Namun setelah dipastikan menjadi AIDS, maka waktu hidup yang tersisa hanya tinggal beberapa tahun saja.

Apabila seseorang telah dinyatakan mengidap HIV/AIDS maka bukan hanya fisik yang menurun, namun juga psikis dan sosialnya turut terpengaruh. Secara fisik, ODHA akan menjadi sangat mudah terserang penyakit karena turunnya kekebalan dalam tubuhnya. Nafsu makan ODHA semakin berkurang sehingga rentan kehilangan berat badan yang drastis yang akan sangat merubah penampilannya. Selain itu, menurunnya kondisi fisik tersebut juga akan berpengaruh terhadap penurunan produktifitas ODHA dalam kesehariannya. 
Secara psikis, ODHA dapat melakukan stigma negatif terhadap dirinya sendiri. HIV dan AIDS masih memiliki citra yang menakutkan di kalangan masyarakat khususnya pada ODHA sendiri, selain karena faktor cara penularannya, AIDS dianggap sebagai suatu vonis hukuman mati. Orang yang pertama kali terdiagnosis HIV dan AIDS seringkali merasa depresi, takut, gundah dan putus asa. Selain itu ODHA akan merasa terasingkan, menganggap orang lain akan menjauhi dirinya karena mengidap penyakit yang ditakuti oleh banyak orang.

Secara sosial, ODHA cenderung mendapatkan hukuman sosial atau stigma negatif oleh masyarakat dalam berbagai cara. Misalnya tindakan-tindakan pengasingan, penolakan, diskriminasi, dan penghindaran atas orang yang diduga terinfeksi HIV, diwajibkannya uji coba HIV untuk mendapatkan pekerjaan atau pendidikan, dan penerapan karantina terhadap orang-orang yang terinfeksi HIV. ODHA sering dihubungkan dengan perilaku negatif homoseksualitas, biseksualitas, pelacuran, dan penggunaan narkoba melalui suntikan. Padahal bisa saja ODHA sama sekali tidak tertular melalui perilaku negatif tersebut melainkan dari transfusi darah atau tertular dari pasangannya.

ODHA cenderung memiliki kondisi yang tidak berdaya baik dari segi fisik, psikis dan sosial. Dengan menurunnya kondisi fisik, psikis dan sosial tersebut tentu akan berpengaruh terhadap kualitas hidupnya. Oleh karena itu, ODHA akan membutuhkan pihak-pihak yang mendampinginya dan memberikan dukungan sosial dalam menghadapi peyakitnya. Situasi ini membutuhkan peran pendamping untuk membantu ODHA mengembalikan kualitas hidupnya menjadi lebih baik.

\section{PERAN PENDAMPING}

Menurut Jumali (dalam Wahyudiana:2001) pendampingan adalah suatu proses fasilitasi yang dilakukan oleh para pendamping yang berperan untuk membantu, mengarahkan dan mencari jalan terhadap berbagai permasalahan. Mengacu pada hal tersebut, maka pendamping adalah orang yang berperan membantu dan mencari jalan terhadap berbagai permasalahan dengan cara memfasilitasinya.

Peran adalah serangkaian perilaku yang diharapkan pada seseorang sesuai dengan posisi sosial yang diberikan baik secara formal maupun secara informal. Peran didasarkan pada preskripsi (ketentuan) dan harapan peran yang menerangkan apa yang individu-individu harus lakukan dalam suatu situasi tertentu agar dapat memenuhi harapan-harapan mereka sendiri atau harapan orang lain menyangkut peran-peran tersebut. (Friedman dalam Zaidin:2010).

Peran pendamping adalah serangkaian perilaku yang diharapkan membantu dan mencari jalan terhadap berbagai permasalahan yang dihadapi klien dengan cara mendampinginya. Mengacu pada Parson (dalam Suharto:2010), terdapat beberapa peran yang dapat dilakukan pekerja sosial dalam melakukan pendampingan terhadap ODHA.

\section{Fasilitator}

Pendamping dapat berfungsi sebagai fasilitor. Istilah fasilitator berasal dari kata fasilitas yang berarti sarana. Maka menfasilitasi berarti memberikan sarana agar tercapai tujuan. Sarana tersebut biasanya untuk memperlancar proses kegiatan. Strategi-strategi khusus untuk mencapai tujuan tersebut meliputi pemberian harapan, pengurangan penolakan dan ambivalensi, pengakuan dan pengaturan perasaan-perasaan, pengidentifikasian dan pendorongan kekuatan-kekuatan personal dan aset-aset sosial, pemilahan masalah menjadi beberapa bagian sehingga lebih mudah dipecahkan, dan pemeliharaan sebuah fokus pada tujuan dan cara-cara pencapaiannya.

Pendamping berperan sebagai fasilitor dengan cara memfasilitasi ODHA agar mampu menangani tekanan psikis dan sosial yang dialami. Tidak mudah bagi ODHA untuk menerima kenyataan bahwa dirinya menderita penyakit yang ditakuti banyak masyarakat. ODHA cenderung bersikap menyalahkan keadaan, tidak bisa menerima keadaan. Banyak ODHA merasa cemas tidak akan lagi diterima di keluarga, lingkungan dan masyarakatnya serta ketakutan untuk menyongsong 
masa depan sehingga ODHA tidak lagi mau bergaul, tidak mau melanjutkan pendidikan atau bahkan melakukan bunuh diri.

Kebanyakan stres yang dialami oleh ODHA karena mereka menghadapi penyakit yang tidak dapat disembuhkan yang membunuh terutama kaum muda, menyebabkan penderitaan yang buruk dengan stigma negatif. Pengasingan, ketidakamanan, dan ketakutan mengenai masa depan dan dampak pada hubungan pribadi serta keluarga. Dalam situasi seperti ini, pendamping memiliki peran memfasilitasi tekanan psikis yang dialami dengan meberikan layanan konsultasi. Pendamping membantu ODHA untuk berusaha menerima statusnya sehingga diharapkan akan menjaga dirinya sendiri, pasangannya, keturunannya dari penyakit yang sama.

Sebagai fasilitator, pendamping juga berperan memberikan motivasi kepada para penderita terutama yang baru mengetahui dirinya terjangkit penyakit HIV/AIDS. Pendamping dapat membangkitkan semangat ODHA karena meskipun tidak dapat disembuhkan namun dapat diperpanjang masa hidupnya dengan obat-obatan tertentu. Meski tidak bisa menyembuhkan, terapi ARV (antiretroviral therapy) bisa memperpanjang hidup pengidap HIV positif dan membuat mereka hidup lebih produktif. Terapi ini mampu mengurangi jumlah virus HIV dengan menghambat penyebaran virusnya. Mengkonsumsi ARV membutuhkan tingkat kedisiplinan yang tinggi. Obatnya harus diminum 12 jam sekali, tidak boleh terlambat. Hal ini harus dilakukan setiap hari tanpa henti, seumur hidupnya.

Obat-obatan tersebut membutuhkan konsistensi dari ODHA sendiri. Oleh karena itu, pendamping berperan memotivasi ODHA agar menguatkan niatnya untuk mendapatkan kesempatan hidup yang lebih lama. Apabila ODHA tidak memiliki motivasi yang baik pada dirinya maka kondisinya akan semakin memburuk. ODHA perlu dimotivasi agar dapat melahirkan kehidupan baru, kesempatan memperbaiki diri dan dapat menjalani kehidupan berdampingan dengan masyarakat.

\section{Broker}

Dalam pengertian umum, seorang beroker berusaha untuk memaksimalkan keuntungan dari transaksi sehingga klien dapat memperoleh keuntungan sebesar mungkin. Dalam konteks pendampingan, peran sebagai broker tidak jauh berbeda dengan peran broker di pasar modal. Dengan demikian ada tiga kata kunci dalam pelaksanaan peran sebagai broker, yaitu: menghubungkan (linking), barang- barang dan pelayanan (goods and services) dan pengontrolan kualitas (quality control).

Pendamping berperan sebagai broker dengan cara menghubungkan kebutuhan ODHA dengan sumber-sumber yang ada disekitarnya. Penting bagi ODHA untuk mengetahui seperti apa HIV/AIDS itu, dimana ODHA bisa mendapatkan pelayanan kesehatan, dan informasi-informasi terkait ODHA lainnya. Pendamping berperan memberikan informasi atau menghubungkan informasi yang dibutuhkan ODHA tersebut.

Informasi mengenai ODHA tersebut perlu diberikan dengan baik agar tidak terjadi salah persepsi. Misalnya informasi yang benar terkait cara penularan virus ini. ODHA tidak akan menularkan virusnya hanya melalui makan dan minum bersama, pemakaian fasilitas umum bersama, seperti telepon umum, WC umum, dan kolam renang, senggolan, pelukan dan kegiatan sehari-hari lainnya atau lewat keringat, dan gigitan nyamuk.

Sebagai broker, pendamping juga dapat berperan menghubungkan ODHA dengan sumber mata pencaharian yang baru jika dibutuhkan. Pada tingkat rumah tangga, keberadaan ODHA cenderung meningkatkan pengeluaran kesehatan dalam suatu rumah tangga bahkan menghilangnya pendapatan karena dikeluarkan dari pekerjaan. Pendamping dapat memberikan informasi kepada ODHA terkait program-program yang dapat menghasilkan pendapatan. Hal ini sangat diperlukan oleh ODHA dan keluarganya untuk mengurangi stres karena pendapatan yang menurun drastis.

\section{Mediator}


Peran mediator diperlukan terutama pada saat terdapat perbedaan yang mencolok dan mengarah pada konflik antara berbagai pihak. Kegiatan-kegiatan yang dapat dilakukan dalam melakukan peran mediator meliputi kontrak perilaku, negosiasi, pendamai pihak ketiga, serta berbagai macam resolusi konflik. Dalam mediasi, upaya-upaya yang dilakukan pada hakekatnya diarahkan untuk mencapai "solusi menang-menang" (win-win solution).

Pendamping berperan sebagai mediator dengan menjadi penengah antara ODHA dengan sistem lingkungan yang menghambatnya. Misalnya menjadi penengah antara ODHA dengan keluarganya, temannya, pasangannya, atau dengan institusi pekerjaan atau pendidikan yang dinaunginya. Lingkungan sekitar ODHA membuat stigma tidak baik, mereka menganggap ODHA tidak bisa hidup normal dan kehilangan hak reproduksi mereka. Padahal jika ditangani dengan tepat, ODHA dapat hidup normal dan berdampingan dengan lingkungan sekitarnya. Oleh karena itu, pendamping perlu jadi mediator antara ODHA dengan lingkungannya.

Penularan virus ini memang dapat lahir dari gaya hidup ODHA yang tidak sehat, baik penggunaan narkoba, alat suntik bergantian, dan seks bebas. Namun bukan tidak mungkin ODHA tertular karena mendapat donor darah dari darah yang telah mengandung virus HIV atau bahkan bawaan lahir dari orangtuanya. Ketika lingkungan terdekat ODHA mengetahui kondisinya, dapat dipastikan tidak semua bisa menerima bahkan cenderung dikucilkan. Alasannya takut tertular dan justru berkembang pada kemarahan mereka karena pola hidup yang dianggap diluar norma. Padahal ODHA memerlukan bantuan orang-orang yang mengerti pengobatan dan memahami psikisnya. Pendamping membantu ODHA meciptakan lingkungan yang positif, keluarga dan temanteman yang ikut mewujudkan kondisi yang menjadikan ODHA tidak makin menderita. Selain itu, pendamping membantu meminimalisir stigma masyarakat sehingga ODHA tetap bisa hidup berdampingan dan berbaur dengan masyarakat.

Pendamping dapat menjadi mediator antara penderita ODHA dengan masyarakat. Misalnya dengan mengadakan pertandingan sepak bola antara ODHA dan masyarakat biasa yang sebenarnya merupakan cara memediasi dengan cara halus. Setelah bertanding, kegiatan ini memberikan pesan bahwa virus ini tidak menular lewat keringat bahkan saat berolahraga bersama. Oleh karena itu pendamping dapat merubah stigma masyarakat yang takut tertular saat bertemu, bersentuhan, berjabat tangan dengan ODHA. Dengan begitu, diharapkan ODHA dan masyarakat sekitarnya akan berhubungan normal kembali seperti biasanya.

\section{Pembela}

Pendamping berperan sebagai pembela dengan cara membela hak ODHA dalam memenuhi kebutuhannya seperti dari diskriminasi. ODHA memiliki hak yang sama terutama pada pendidikan, kesehatan dan pekerjaan. Pendamping perlu membela ODHA dari diskriminasi di lingkungan institusi baik di institusi pendidikan, institusi, pekerjaan serta institusi kesehatan.

Di institusi pendidikan, banyak ODHA anak dan anak dari ODHA yang tidak mau lagi melanjutkan pendidikan karena mendapat perlakuan yang berbeda dari guru maupun rekan sesama siswa. Lebih buruk lagi, masih banyak institusi sekolah yang tidak mau menerima ODHA anak atau anak ODHA untuk bersekolah di institusinya.

Di Institusi pekerjaan, saat ini banyak perusahaan yang mengharuskan pelamarnya melakukan tes diagnostik HIV. Bila hasilnya positif, maka pelamar tentu saja tidak diterima bekerja. Tindakan lainnya adalah mencutikan pegawai ODHA dalam waktu yang tidak terbatas, pemecatan secara sepihak, tidak mendapatkan jaminan kesehatan tenaga kerja dan sebagainya.

Di Institusi kesehatan pun masih banyak terjadi tindakan diskriminatif walaupun kebanyakan tenaga kesehatan telah memiliki pengetahuan yang cukup memadai mengenai HIV dan AIDS. Tindakan diskriminatif ini antara lain adalah tenaga kesehatan yang tidak mau melakukan kontak fisik seperti jabat tangan dan pemeriksaan fisik dasar dengan ODHA, tenaga kesehatan tidak mau mengambil sampel darah ODHA dan sebagainya karena takut terular. 


\section{Pelindung}

Pendamping berperan sebagai pelindung dengan cara melindungi ODHA dari situasi yang rentan dan tidak menguntungkan bagi ODHA seperti stigma negatif. Terdapat banyak stigma negatif yang didapatkan oleh ODHA. Menurut Herek dalam Nurhayati, stigma terkait AIDS adalah segala persangkaan, penghinaan dan diskriminasi yang ditujukan kepada ODHA serta individu, kelompok atau komunitas yang berhubungan dengan ODHA tersebut. Pendamping melindungi ODHA dari diskriminasi yang didapatkan ODHA dan orang-orang yang hidup bersama ODHA.

Pendamping perlu melindungi ODHA dari diskriminasi di lingkungan individual seperti pengucilan atau pembuangan ODHA ke tempat terpencil diluar kota, pengucilan ODHA dari daftar waris keluarga, serta tuntutan perceraian dari pasangan. Pendamping perlu melindungi ODHA dari diskriminasi di lingkungan komunitas seperti halnya pada lingkungan keluarga, stigma dan diskriminasi di lingkungan komunitas pun tindakan diskriminatif yang sebelumnya ada seperti pengucilan, tidak mau berjabat tangan atau melakukan kontak dengan ODHA masih ada di tengahtengah masyarakat.

Pendamping perlu melindungi ODHA dari diskriminasi di lingkungan kebijakan seperti kebijakan yang menyatakan bahwa perusahaan tidak boleh memecat karyawan ODHA. Pada kenyataannya, sampai saat ini masih banyak ditemui kasus karyawan dipecat karena terdiagnosis HIV. Kebijakan lainnya ialah pelarangan pemeriksaan HIV pada pelamar kerja. Kenyataannya, masih banyak perusahaan yang meminta pelamar kerja untuk melakukan tes HIV terlebih dahulu sebelum diterima kerja.

\section{PENUTUP}

Peran pendamping bagi ODHA menjadi sangat strategis dalam upaya mengembalikan keadaan dan kondisi ODHA menjadi lebih baik dari sebelumnya. Terdapat lima peran pendamping yang dapat dilakukan pekerja sosial dalam melakukan pendampingan terhadap ODHA. Pertama sebagai fasilitator, pendamping berperan memfasilitasi ODHA agar mampu menangani tekanan psikis dan sosial yang dialami. Kedua sebagai broker, pendamping berperan menghubungkan kebutuhan ODHA dengan sumber-sumber yang ada disekitarnya. Ketiga sebagai mediator, pendamping berperan sebagai penengah bagi ODHA dengan sistem lingkungan yang menghambatnya. Keempat sebagai pembela, pendamping berperan dalam membela hak ODHA dalam memenuhi kebutuhannya. Dan kelima sebagai pelindung, pendamping berperan melindungi ODHA dari situasi yang rentan dan tidak menguntungkan bagi ODHA.

ODHA bukanlah orang yang harus ditakuti, namun harus dirangkul untuk diberi semangat. Dukungan dan semangat yang diberikan oleh sekitarnya dapat menolong ODHA untuk keluar dari keterpurukan dan membantu ODHA untuk memberikan yang terbaik dari hidupnya. Oleh karena itu, pendamping memiliki peran untuk mengubah keadaan tidak berdaya yang dialami ODHA tersebut menjadi berdaya kembali.

\section{DAFTAR PUSTAKA}

Nurhayati, Eka. 2013. Stigma dan Diskriminasi Terhadap ODHA di Kota Bandung. Program Pascasarjana Program Studi Ilmu Kesehatan Masyarakat Universitas Padjadjaran

Nurnita, Widaykusuma. 2013. Peran Pendamping Dalam Program Pendampingan Dan Perawatan Sosial Lanjut Usia Di Lingkungan Keluarga (Home Care): Studi Tentang Pendamping Di Yayasan Pitrah Sejahtera, Kelurahan Cilincing, Kecamatan Cilincing Jakarta Utara. Pusat Pendidikan dan Pelatihan Kementerian Sosial RI

Suharto, Edi. 2010. Membangun Masyarakat Memberdayakan Masyarakat "Kajian Strategis Pembangunan Kesejahteraan Sosial dan Pekerjaan Sosial. Bandung : Refika Aditama.

Suharto, Edi. 2003. Kemiskinan dan Keberfungsian Sosial. Hasil Penelitian. STKS Bandung Press 
Wahyudiyana, Singgih. 2001. Strategi pendampingan dalam pemberdayaan komunitas petani : Kajian terhadap pemberdayaan komunitas petani melalui kegiatan pendampingan sosial yang dilaksanakan sekretariat Bina Desa /INDHRRA Jakarta: Studi kasus pendampingan sosial komunitas petani di desa Jambangan, Kecamatan Paron, Kabupaten Ngawi, Propinsi Jawa Timur Singgih. Jurnal Tesis Ilmu Sosiologi Kekhususan Kesejahteraan Sosial UI.

Zaidin, Ali. 2010. Pengantar Keperawatan Keluarga. Jakarta : EGC

Sumber lainnya :

http://rumahcemara.org/ (diunduh pada tanggal 17 Desember 2014 pukul 19.30)

http://www.spiritia.or.id/cst/bacacst.php?artno=1012\&menu=perawmenu (diunduh pada tanggal 17 Desember 2014 pukul 19.10)

http://www.matakubesar.com/2014/11/melampaui-mimpi.html (diunduh pada tanggal 17 Desember 2014 pukul 20.00)

http://sulis-wanto.blogspot.com/2012/12/seluk-beluk-hivaids-dan-penjabaranya.html (diunduh pada tanggal 17 Oktober 2014 pukul 19.00) 